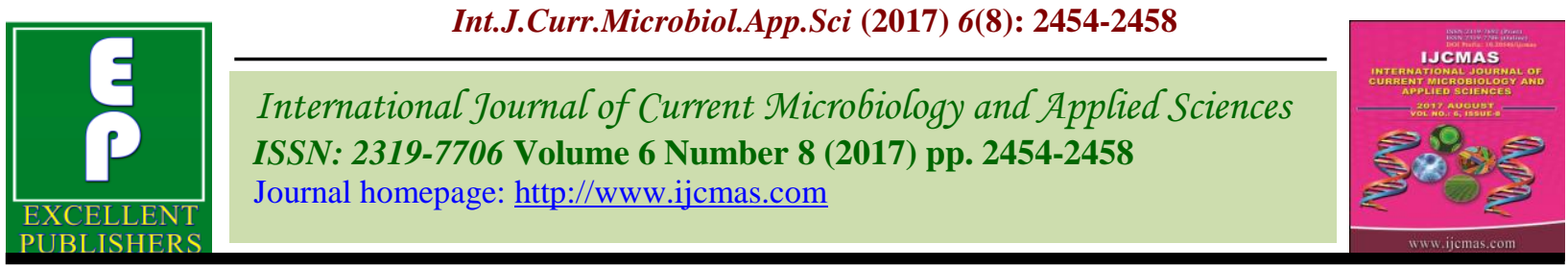

Original Research Article https://doi.org/10.20546/ijcmas.2017.608.290

\title{
Integrated Management of Major Fungal Diseases of Tomato in Kashmir Valley, India
}

\author{
Ali Anwar, Mudasir Bhat*, Mohmmad Najeeb Mughal, \\ G. Hassan Mir and V.K. Ambardar \\ Division of Plant Pathology, SKUAST-K, Shalimar, J\&K-190025, India \\ *Corresponding author
}

\section{A B S T R A C T}

A field trial was conducted to evaluate effective management practices and to develop integrated management strategy for fungal diseases of tomato crop. The treatments comprised of sheep manure @ $3 \mathrm{~kg} / \mathrm{m}^{2}$, mulching by mustard straw @ $4 \mathrm{~kg} / \mathrm{m}^{2}$; seedling dip in Trichoderma harzianum, Pseudomonas fluorescence each @ $4 \mathrm{~g} / \mathrm{L}$ water and carbendazim 50 WP @ $1 \mathrm{~g} / \mathrm{L}$ water) and 2 foliar sprays of mancozeb 75 WP @ 0.2\% followed by carbendazim 50 WP @ 0.05\% 20 days after the onset of disease. The removal of basal infected leaves and foliar sprays with mancozeb $75 \mathrm{WP}$ or carbendazim $50 \mathrm{WP}$ proved best exhibiting a disease severity of $6.5 \%$ in case of Septoria leaf spot and a minimum disease severity of $1.6 \%$ in case of Alternaria loaf spot, while seedlings root dip in carbendazim 50 WP was least effective against both the diseases. Minimum rotted fruits $(0.03$ $\mathrm{kg} / \mathrm{plot}$ was observed in spray treatments of mancozeb 75 WP @ $2 \mathrm{~g} / \mathrm{L}$ water followed by carbendazim 50 WP @ $0.5 \mathrm{~g} / \mathrm{L}$ water, whereas, T. harzianum (root dip @ $4 \mathrm{~g} / \mathrm{L}$ water $)$ resulted highest roted fruits $(0.28 \mathrm{~kg} / \mathrm{plot})$. Different management practices like stacking in combination with fungicides could therefore be integrated for effective management of the diseases.

\section{Introduction}

Tomato (Lycopersicon esculentum L.) originated South America belongs to Solanaceae family is a widely grown vegetable in the world. The leading producer of tomato in the world is USA followed by China, Italy, Turkey, Egypt, Spain, Romania, Brazil and Greece. It is the popular vegetable of Kashmir because of its taste, colour and high nutritive value and also for its diversified use. In Kashmir Valley, the crop is grown over an area of 1500 hectares with an average yield of 400-500 q/ha (Wani, 2011). Tomato is attacked by variety of pathogens; predominant being the fungal fruit rots (Taskeen-un-Nisa et al., 2011). These fungal rots are responsible for causing serious production problems and become menace for successful cultivation of tomatoes in valley. Fungal rots are world-wide in occurrence and have been reported almost in all parts of the world. According to Sokhi and Sohi (1982), the destructive pathogen causing fruit rots on tomato is present in parts of the country where moisture is plentiful and temperatures are moderate to favour their development. Besides, Septoria leaf spot is very common 
foliar disease of field-grown tomatoes in the Kashmir valley. Managing diseases is critical to successful tomato production because diseases, unfortunately, are a common occurrence wherever tomatoes are grown. An important aspect of effective management is accurate and early identification to ensure control practices used are appropriate. Protective sprays of non-systemic fungicides like dithio-carbamates (Choulwar and Datar 1992), Copper oxychloride (Maheshwari et al., 1991) and Captan (Vakalounakis and Malathrakis 1988) were found effective up to some extent but eco-friendly and complete control measure is still lacking.

The IDM practices not only save the crop from the diseases but also reduce the possibility of attack by the other pathogens (viruses, bacteria and nematodes) to tomato crop in a cropping season (Afroz et al., 2008). There is a great need to carry out farmer level research aiming to develop a holistic disease management model to manage the major diseases of tomato. The present study was therefore undertaken to develop an effective and eco-friendly management practices against major fungal diseases of tomato.

\section{Materials and Methods}

A field trial was laid at research farm of SKUAST in a randomized block design. The 35 day old tomato seedlings cv. ' $\mathrm{SH}-1$ ' were transplanted in a plot size of $2.0 \times 1.5 \mathrm{~m}^{2}$ at a plant spacing of $40 \times 30 \mathrm{~cm}$. The treatments comprised of different management practices [organic amendment (sheep manure)] @ 3 $\mathrm{kg} / \mathrm{m}^{2}$, cultural practices (stacking, mulching by mustard pod straw @ $4 \mathrm{~kg} / \mathrm{m}^{2}$, removal of basal infected leaves); seedling root-dip in bioagents (Trichoderma harzianum, Pseudomonas fluorescence; each @ $4 \mathrm{~g} / \mathrm{L}$ water) and fungicide carbendazim 50 WP @ 1 $\mathrm{g} / \mathrm{L}$ water) and 2 foliar sprays (mancozeb 75 WP @ $0.2 \%$ followed by carbendazim 50 WP
@ $0.05 \%$ ) 20 days after the onset of disease including an untreated checks. Each treatment was replicated 3 times. All the agronomical practices except fungicidal sprays were adopted as per recommended packages practices. The treatments comprised of different management practices viz. $\mathrm{T}_{1^{-}}$ Staking, $\mathrm{T}_{2}$-Mulching (mustard pod straw @ $4 \mathrm{~kg} / \mathrm{m}^{2}$ ), $\mathrm{T}_{3^{-}}$Removal of basal leaves, $\mathrm{T}_{4^{-}}$ Sprays of mancozeb 75WP @ 2 g/L water followed by carbendazim 50 WP @ $0.5 \mathrm{~g} / \mathrm{L}$ water, $\mathrm{T}_{5}$ - Staking + Mulching (mustard pod straw @ $\left.4 \mathrm{~kg} / \mathrm{m}^{2}\right), \mathrm{T}_{6^{-}}$Staking + Removal of basal leaves, $\mathrm{T}_{7}$-Staking + Sprays of mancozeb 75WP @ $2 \mathrm{~g} / \mathrm{L}$ water followed by carbendazim 50 WP @ $0.5 \mathrm{~g} / \mathrm{L}$ water, $\mathrm{T}_{8^{-}}$ Mulching (mustard pod straw @ $4 \mathrm{~kg} / \mathrm{m}^{2}+$ Removal of basal leaves, $\mathrm{T}_{9^{-}}$Mulching (mustard pod straw @ $4 \mathrm{~kg} / \mathrm{m}^{2}+$ Sprays of mancozeb 75WP @ 2 g/L water followed by carbendazim 50 WP @ $0.5 \mathrm{~g} / \mathrm{L}$ water, $\mathrm{T}_{10^{-}}$ Removal of basal leaves + Sprays of mancozeb 75WP @ 2 g/L water followed by carbendazim $50 \mathrm{WP} @ 0.5 \mathrm{~g} / \mathrm{L}$ water, $\mathrm{T}_{11^{-}}$ Staking + Mulching (mustard pod straw @ 4 $\left.\mathrm{kg} / \mathrm{m}^{2}\right)+$ Removal of basal leaves, $\mathrm{T}_{12^{-}}$ Staking + Mulching (mustard pod straw @ 4 $\mathrm{kg} / \mathrm{m}^{2}$ ) + Sprays of mancozeb 75WP @ $2 \mathrm{~g} / \mathrm{L}$ water followed by carbendazim 50 WP @ 0.5 $\mathrm{g} / \mathrm{L}$ water, $\mathrm{T}_{13}-$ Mulching (mustard pod straw @ $4 \mathrm{~kg} / \mathrm{m}^{2}+$ Removal of basal leaves + Sprays of mancozeb 75WP @ 2 g/L water followed by carbendazim 50 WP @ $0.5 \mathrm{~g} / \mathrm{L}$ water, $\mathrm{T}_{14^{-}}$Staking+ Removal of basal leaves + Sprays of Mancozeb 75WP @ 2g/L water followed by Carbendazim 50WP @ $0.5 \mathrm{~g} / \mathrm{L}$ water and $\mathrm{T}_{15^{-}}$Staking + Removal of basal leaves + Mulching (mustard pod straw @ 4 $\mathrm{kg} / \mathrm{m}+$ Sprays of mancozeb 75WP @ $2 \mathrm{~g} / \mathrm{L}$ water followed by carbendazim 50 WP @ 0.5 $\mathrm{g} / \mathrm{L}$ water 20 days after the onset of disease including an untreated checks. Each treatment was replicated 3 times. Data on disease severity of foliage was recorded by using 0-5 rating scale and that of fruits on 0-4 rating scale (Sokhi and Sohi, 1974). Statistical 
analysis of the data was done as per the methods given by Gomez and Gomez, 1984.

\section{Results and Discussion}

Among the various fungal diseases, Septoria leaf spot, Alternaria leaf spot, buckeye fruit rot and Alternaria fruit rot were found to be the major diseases occurring on tomato crop. Septoria leaf spot disease and buckeye fruit rot were more severe than other disease in all three years. All the treatments significantly reduced severity of both the diseases (Septoria leaf spot and buckeye rot). $\mathrm{T}_{15}$, Staking + Removal of basal leaves + Mulching (mustard pod straw @ 4 kg/m +Sprays of mancozeb 75WP @ 2 g/L water followed by carbendazim 50 WP @ $0.5 \mathrm{~g} / \mathrm{L}$ water proved best in controlling both the diseases and exhibited a minimum disease severity of $4.4 \%$ with highest disease of control $80.85 \%$ in case of Septoria leaf spot and a minimum disease severity of $1.40 \%$ with highest disease control of $87.04 \%$ in case of Alternaria leaf spot (Table 1). The control plot showed Septoria and Alternaria leaf spot severities of 22.98 and $10.81 \%$, respectively. $\mathrm{T}_{14}$ was next best treatment, while $\mathrm{T}_{2}$, Mulching (mustard pod straw @ $4 \mathrm{~kg} / \mathrm{m}^{2}$ ) was least effective exhibiting disease severity of 18.25 and $7.19 \%$ against both the diseases, respectively.

Minimum rotted fruits $(0.65 \mathrm{~kg} / \mathrm{plot}$ were observed in treatment $T_{15}$ followed by $T_{11}$, whereas, $T_{3}$ resulted highest rotted fruits $(1.35$ $\mathrm{kg} /$ plot) (Table 2). Further, $\mathrm{T}_{15}$ also showed superiority on other treatments in respect of producing highest healthy fruits yield of 4.65 $\mathrm{kg} /$ pot followed by $\mathrm{T}_{8}$ which produced healthy fruit yield of $4.11 \mathrm{~kg} / \mathrm{plot}$.

Table.1 Effect of various management practices on the major foliar diseases of Tomato variety $(\mathrm{SH}-1)$

\begin{tabular}{|c|c|c|}
\hline \multirow[t]{2}{*}{ Treatment } & \multicolumn{2}{|c|}{ Severity of foliage diseases $(\%)$} \\
\hline & Septoria leaf spot & Alternaria leaf spot \\
\hline $\mathrm{T}_{1}$ Staking & 14.43 & 6.39 \\
\hline $\mathrm{T}_{2}$ Mulching (mustard pod straw @ $4 \mathrm{~kg} / \mathrm{m}^{2}$ ) & 18.25 & 7.19 \\
\hline $\mathrm{T}_{3}$ Removal of basal leaves & 8.08 & 5.50 \\
\hline $\begin{array}{l}\mathrm{T}_{4} \text { Sprays of mancozeb 75WP @ } 2 \mathrm{~g} / \mathrm{L} \text { water followed by carbendazim } 50 \text { WP @ } 0.5 \mathrm{~g} / \mathrm{L} \\
\text { water }\end{array}$ & 6.53 & 3.12 \\
\hline $\mathrm{T}_{5}$ Staking + Mulching (mustard pod straw @ $4 \mathrm{~kg} / \mathrm{m}^{2}$ ) & 12.45 & 5.33 \\
\hline $\mathrm{T}_{6}$ Staking + Removal of basal leaves & 7.20 & 4.50 \\
\hline $\begin{array}{l}\mathrm{T}_{7} \text { Staking }+ \text { Sprays of mancozeb 75WP @ } 2 \mathrm{~g} / \mathrm{L} \text { water followed by carbendazim } 50 \mathrm{WP} @ \\
0.5 \mathrm{~g} / \mathrm{L} \text { water }\end{array}$ & 10.30 & 2.73 \\
\hline $\mathrm{T}_{8}$ Mulching (mustard pod straw @ $4 \mathrm{~kg} / \mathrm{m}^{2}+$ Removal of basal leaves & 6.10 & 4.63 \\
\hline $\begin{array}{l}\mathrm{T}_{9} \text { Mulching (mustard pod straw @ } 4 \mathrm{~kg} / \mathrm{m}^{2}+\text { Sprays of mancozeb 75WP @ } 2 \mathrm{~g} / \mathrm{L} \text { water } \\
\text { followed by carbendazim } 50 \mathrm{WP} @ 0.5 \mathrm{~g} / \mathrm{L} \text { water }\end{array}$ & 11.16 & 2.50 \\
\hline $\begin{array}{l}\mathrm{T}_{10} \text { Removal of basal leaves + Sprays of mancozeb 75WP @ } 2 \mathrm{~g} / \mathrm{L} \text { water followed by } \\
\text { carbendazim } 50 \mathrm{WP} @ 0.5 \mathrm{~g} / \mathrm{L} \text { water }\end{array}$ & 7.05 & 2.34 \\
\hline $\mathrm{T}_{11}$ Staking + Mulching (mustard pod straw @ 4 kg/m²) + Removal of basal leaves & 6.95 & 3.88 \\
\hline $\begin{array}{l}\mathrm{T}_{12} \text { Staking + Mulching (mustard pod straw @ } 4 \mathrm{~kg} / \mathrm{m}^{2} \text { ) + Sprays of mancozeb 75WP @ } 2 \\
\mathrm{~g} / \mathrm{L} \text { water followed by carbendazim } 50 \mathrm{WP} @ 0.5 \mathrm{~g} / \mathrm{L} \text { water }\end{array}$ & 9.55 & 2.25 \\
\hline $\begin{array}{l}\mathrm{T}_{13} \text { Mulching (mustard pod straw @ } 4 \mathrm{~kg} / \mathrm{m}^{2}+\text { Removal of basal leaves + Sprays of } \\
\text { mancozeb 75WP @ } 2 \mathrm{~g} / \mathrm{L} \text { water followed by carbendazim } 50 \mathrm{WP} @ 0.5 \mathrm{~g} / \mathrm{L} \text { water }\end{array}$ & 5.35 & 1.97 \\
\hline $\begin{array}{l}\mathrm{T}_{14} \text { Staking + Removal of basal leaves + Sprays of mancozeb 75WP @ } 2 \mathrm{~g} / \mathrm{L} \text { water followed } \\
\text { by carbendazim } 50 \text { WP @ } 0.5 \mathrm{~g} / \mathrm{L} \text { water }\end{array}$ & 4.75 & 1.75 \\
\hline $\begin{array}{l}\mathrm{T}_{15} \text { Staking + Removal of basal leaves + Mulching (mustard pod straw @ } 4 \mathrm{~kg} / \mathrm{m}+\text { Sprays of } \\
\text { mancozeb 75WP @ } 2 \mathrm{~g} / \mathrm{L} \text { water followed by carbendazim } 50 \mathrm{WP} @ 0.5 \mathrm{~g} / \mathrm{L} \text { water }\end{array}$ & 4.40 & 1.40 \\
\hline $\mathrm{T}_{16}$ Check/Control & 22.98 & 10.81 \\
\hline $\mathrm{CD}(\mathrm{P}=0.05)$ & 6.91 & 2.91 \\
\hline
\end{tabular}


Table.2 Effect of various management practices on the severity of major Fungal fruit rots and fruit yield

\begin{tabular}{|c|c|c|c|c|}
\hline \multirow[t]{2}{*}{ Treatment } & \multicolumn{2}{|c|}{ Severity of fruit rots $(\%)$} & \multicolumn{2}{|c|}{ Yield (kg/plot) } \\
\hline & $\begin{array}{l}\text { Buckeye } \\
\text { rot }\end{array}$ & $\begin{array}{l}\text { Alternaria } \\
\text { rot }\end{array}$ & $\begin{array}{l}\text { Rotted } \\
\text { fruits }\end{array}$ & $\begin{array}{l}\text { Healthy } \\
\text { fruits }\end{array}$ \\
\hline $\mathrm{T}_{1}$ Staking & 2.50 & 2.45 & 0.71 & 3.70 \\
\hline $\mathrm{T}_{2}$ Mulching (mustard pod straw @ $4 \mathrm{~kg} / \mathrm{m}^{2}$ ) & 2.01 & 2.27 & 0.88 & 4.01 \\
\hline $\mathrm{T}_{3}$ Removal of basal leaves & 2.72 & 1.32 & 1.35 & 3.10 \\
\hline $\begin{array}{l}\mathrm{T}_{4} \text { Sprays of mancozeb } 75 \mathrm{WP} @ 2 \mathrm{~g} / \mathrm{L} \text { water followed by carbendazim } 50 \mathrm{WP} @ \\
0.5 \mathrm{~g} / \mathrm{L} \text { water }\end{array}$ & 1.65 & 1.75 & 1.25 & 3.35 \\
\hline $\mathrm{T}_{5}$ Staking + Mulching (mustard pod straw @ $4 \mathrm{~kg} / \mathrm{m}^{2}$ ) & 1.87 & 2.05 & 0.70 & 3.72 \\
\hline $\mathrm{T}_{6}$ Staking + Removal of basal leaves & 2.30 & 1.70 & 0.69 & 3.75 \\
\hline $\begin{array}{l}\mathrm{T}_{7} \text { Staking + Sprays of mancozeb } 75 \mathrm{WP} @ 2 \mathrm{~g} / \mathrm{L} \text { water followed by carbendazim } \\
50 \mathrm{WP} @ 0.5 \mathrm{~g} / \mathrm{L} \text { water }\end{array}$ & 1.47 & 1.55 & 1.21 & 3.50 \\
\hline $\mathrm{T}_{8}$ Mulching (mustard pod straw @ $4 \mathrm{~kg} / \mathrm{m}^{2}+$ Removal of basal leaves & 1.93 & 1.75 & 0.84 & 4.11 \\
\hline $\begin{array}{l}\mathrm{T}_{9} \text { Mulching (mustard pod straw @ } 4 \mathrm{~kg} / \mathrm{m}^{2}+\text { Sprays of mancozeb } 75 \mathrm{WP} @ 2 \mathrm{~g} / \mathrm{L} \\
\text { water followed by carbendazim } \\
50 \mathrm{WP} @ 0.5 \mathrm{~g} / \mathrm{L} \text { water }\end{array}$ & 1.45 & 1.67 & 1.20 & 3.58 \\
\hline $\begin{array}{l}\mathrm{T}_{10} \text { Removal of basal leaves + Sprays of mancozeb 75WP @ } 2 \mathrm{~g} / \mathrm{L} \text { water followed } \\
\text { by carbendazim } 50 \text { WP @ } 0.5 \mathrm{~g} / \mathrm{L} \text { water }\end{array}$ & 1.45 & 1.69 & 1.19 & 3.69 \\
\hline$T_{11}$ Staking + Mulching (mustard pod straw @ $4 \mathrm{~kg} / \mathrm{m}^{2}$ ) + Removal of basal leaves & 1.95 & 2.19 & 0.68 & 3.77 \\
\hline $\begin{array}{l}\left.\mathrm{T}_{12} \text { Staking + Mulching (mustard pod straw @ } 4 \mathrm{~kg} / \mathrm{m}^{2}\right)+ \text { Sprays of mancozeb } \\
75 \mathrm{WP} @ 2 \mathrm{~g} / \mathrm{L} \text { water followed by carbendazim } 50 \mathrm{WP} @ 0.5 \mathrm{~g} / \mathrm{L} \text { water }\end{array}$ & 1.45 & 1.49 & 1.14 & 3.88 \\
\hline $\begin{array}{l}\mathrm{T}_{13} \text { Mulching (mustard pod straw @ } 4 \mathrm{~kg} / \mathrm{m}^{2}+\text { Removal of basal leaves + Sprays of } \\
\text { mancozeb 75WP @ } 2 \mathrm{~g} / \mathrm{L} \text { water followed by carbendazim } 50 \mathrm{WP} @ 0.5 \mathrm{~g} / \mathrm{L} \text { water }\end{array}$ & 1.49 & 1.55 & 1.15 & 3.85 \\
\hline $\begin{array}{l}\mathrm{T}_{14} \text { Staking + Removal of basal leaves + Sprays of mancozeb 75WP @ } 2 \mathrm{~g} / \mathrm{L} \text { water } \\
\text { followed by carbendazim } 50 \mathrm{WP} @ 0.5 \mathrm{~g} / \mathrm{L} \text { water }\end{array}$ & 1.35 & 1.48 & 1.09 & 3.98 \\
\hline $\begin{array}{l}\mathrm{T}_{15} \text { Staking + Removal of basal leaves + Mulching (mustard pod straw @ } 4 \mathrm{~kg} / \mathrm{m} \\
+ \text { +Sprays of mancozeb 75WP @ } 2 \mathrm{~g} / \mathrm{L} \text { water followed by carbendazim } 50 \mathrm{WP} @ 0.5 \\
\mathrm{~g} / \mathrm{L} \text { water }\end{array}$ & 1.27 & 1.34 & 0.65 & 4.65 \\
\hline $\mathrm{T}_{16}$ Check/Control & 3.48 & 3.75 & 1.38 & 3.02 \\
\hline $\mathrm{CD}(\mathrm{P}=0.5)$ & 0.72 & 0.91 & 0.12 & 1.14 \\
\hline
\end{tabular}

Successful integrated management of fungal foliar and fruit diseases of tomato has been important in temperate climate of mountaneous Kashmir where cultivation of tomato crop attained the generally ideal environmental conditions for occurrence of dreaded diseases. The diseases affect all the plant parts reducing the vigorosity and quality produce of tomato hence various approaches have been integrated for combating and mitigating the production and productivity of tomato (Wani, 2011). Out of the inevitable approaches, cultural practices and spray of the crop with fungicides proved to be most effective where scarce occurrence of disease spreading was recorded. In spite of foliar diseases, the minimum incidence of fruit diseases like buckeye rot and Alternaria rot were also found which might be due to removal of basal and old leaves of the crop which provided good aeration and favourable micro-climate of the crop canopy, that is the reason pathogens of different diseases could not develop adequately and might be lacking of favourable habitat for the pathogen as the attack over the old and basal leaves (Banyal et al., 2008 and Begum, 2001). It is evident that when fungicide was to be sprayed over the crop, the secondary and aerial infection has also impeded and significant yield was harvested with the quality produce of fruits. Meanwhile the other approaches viz. stacking and seedling dip with bioagents were also effective the diseases. Several studies have been made with respect to occurrence of the disease severity, yield losses and the 
integrated management in tomato crop (Aulakh and Grover, 1969; Iqbal et al., 2003;; Hossain and Fakir, 2001).Stacking, removal of infected basal leaves coupled with sprays of mancozeb 75WP @ $0.2 \%$ followed by carbendazim 50WP @0.05\% were therefore recommended for integrated management of the diseases.

\section{Acknowledgement}

The authors are highly thankful to the directorate of research SKUAST-K and head of the department for providing the financial assistance to carry out the research.

\section{References}

Afroz M, Ashrafuzzaman M, Ahmed M N, Ali M E and Azim M R 2008. Integrated management of major fungal diseases of tomato. Int. J. Sustain. Crop Prod.3 (2):54-59.

Aulakh K S, Grover R K 1969. Use of oil for controlling ripe fruit rots of tomato caused by Phomadestructiva. Plant Prot. Bull., FAO. 17: 90-91.

Banyal D K, Mankotia V, Sugha S K 2008. Integrated management of tomato collar rot caused by Sclerotium rolfsii. J. Mycol. Plant Pathol, 38:165-167.

Begum F 2001. Integrated management of early blight, late blight and wilt diseases of tomato cv. Pusa Ruby. M.S Thesis. Department of Plant Pathology, Bangladesh Agricultural University, Mymensingh. 16p.

Choulwar A B and Datar V V 1992. Management of tomato early blight with chemicals. J Maharastra Agric Uni,17: 214-216.

Gomez KA and Gomez AA 1984.Statistical Procedures for Agricultural Research. John Wiley and Sons, Inc 680p.

Hossain I and G A. Fakir 2001.Biological control of seed-borne pathogens of some crops.1st ed. Seed Pathology Laboratory (SPL), Bangladesh Agricultural University (BAU), Mymnensingh, Bangladesh. 30 pp

Iqbal S M, Ghafoor Z A, Haqqani 2003. Pathogenicity and fungicidal efficacy for sclerotinia rot of brinjal. Int. J. Agric. Biol., 5(4): 618-620.

Maheshwari S K, Gupta P C and Gandhi SK 1991.Evaluation of various fungitoxicants against early blight of tomato (Lycopersicon esculentum Mill.). Agric Sci Digest, 11: 201-202.

Sokhi S S and Sohi H S 1974. Chemical control of buckeye rot of tomato. Indian Phytopathology27: 444-445.

Sokhi S S and Sohi H S 1982.Assessment of losses in tomato caused by buckeye rot. Indian Phytopathol, 35: 675-676.

Taskeen-un-Nisa, Wani A. H, Bhat M Y, Pala S. A. and Mir R. A. 2011. In vitro inhibitory effect of fungicides and botanicals on mycelia growth and spore germination of Fusarium oxysporum. $J$ Biopest, 4: 53-56.

Vakalounakis D J, Malathrakis N E 1988. A cucumber disease caused by Alternaria alternate and its control. J Phytopathol, 12: 325-326.

Wani A H 2011. An overview of the fungal rot of tomato. Mycopath, 9(1): 33-38.

\section{How to cite this article:}

Ali Anwar, Mudasir Bhat, Mohmmad Najeeb Mughal, G. Hassan Mir and Ambardar, V.K. 2017. Integrated Management of Major Fungal Diseases of Tomato in Kashmir Valley. Int.J.Curr.Microbiol.App.Sci. 6(8): 2454-2458. doi: https://doi.org/10.20546/ijcmas.2017.608.290 